\title{
Den inderlige deltagelse
}

\author{
Katrine Frøkjer Baunvig
}

Denne artikel baserer sig på det arbejde, der ligger til grund for min religionsvidenskabelige ph.d.-afhandling, Forsamlingen forst. N.F.S. Grundtvigs og Émile Durkheims syn på fallesskab. Titlen dækker over en komparativ undersøgelse af på den ene side Grundtvigs forståelse af de mekanismer, som opretholder såvel verdslige som religiøse fællesskaber. På den anden side står den franske religionssociolog Émile Durkheims (1858-1917) religionsteori, der ud over religion også angår 'samfundsdannelsesdynamikker' mere overordnet betragtet samt hans pædagogiske arbejde. Det er særligt deres understregning af den konkrete fysiske forsamlings betydning for fællesskabers opretholdelse, der er central for sammenligningen. Men derudover har det vist sig, at de på en beslægtet måde tildeler 'historien' stor betydning både akademisk-metodisk samt kulturelt-identitetsmæssigt. Endelig står de begge i mere eller mindre direkte forbindelse med den romantiske tankestrømning - særligt i den brede 'folkeorienterede' variant, som ofte knyttes til J.G. Herders forfatterskab.

Jeg vil i det følgende give eksempler på undersøgelsens fund og konklusioner med eksklusivt fokus på den del af undersøgelsen, som fokuserer på Grundtvigs syn på salmesangens funktion i gudstjenesten. ${ }^{1}$

\section{Grundtvigs refleksioner over og ambitioner for det religiøse fællesskab}

Årtierne omkring år 1800 var kendetegnet ved en række moderniserende reformer på samfundets mest afgørende områder: fordeling af jordbesid-

1 For en overordnet præsentation af afhandlingens komparative fund se Baunvig (2015). For bidrag til Durkheim-forskningen specifikt se Baunvig (2014a). 
delser, indretning af skolerne og kirkerne. Samtidig var det en periode, der var blevet optaget af fortiden. Museer som Nationalmuseet var blevet oprettet, $^{2}$ og den såkaldte 'Oldsagskommission' nedsat (Jakobsen 2007). Arkæologiske udgravningsprojekter omkring gravhøje blev sat i gang, og i litteraturen dyrkede man middelaldergotik i romaner (Fay 2002) såvel som lyrik (Lundgreen-Nielsen 2010). Dette er blot antydningsvise eksempler på en generel tidsstrømning. Man ønskede at tilpasse gamle institutioner til nye tider. Under de mange tiltag ulmede en krisestemning, som blot blev understreget af de storpolitiske begivenheder, Den Franske Revolution og Napoleonskrigene.

Denne stemning var ikke mindst udtalt i kirken. Skal man tro de mange beretninger fra perioden, stod de danske kirker tomme og misvedligeholdte i årene omkring år 1800. Optællingsundersøgelser til kortlægning af kirkegangen findes ikke herhjemme. ${ }^{3}$ Men at det var en reel og presserende bekymring blandt landets præster, at tilknytningen til kirken svækkedes, kan der ikke være tvivl om. ${ }^{4}$ Bag denne formulering ligger $\mathrm{Hal}$ Kochs stadig friske og præcise beskrivelse af problemstillingen: "Kærnen i Sagen var, at den middelalderlige Enhedskultur var ved at gaa i Opløsning" (1954, 92). Kristendommen som fundament for menneskelivet var ikke længere en selvfølge, og præstens autoritet var svækket. ${ }^{5}$ Koch leverer

${ }^{2}$ For en beskrivelse af museumsvæsenets dannelse, som fandt sted over hele Europa i denne periode, se Bennett 1995.

3 Til gengæld foreligger der demografisk-sociologiske undersøgelser, som kan indikere, at et fald i befolkningstilvæksten sammenholdt med en uændret tæthed i kirkebyggeriet i sig selv kunne have bidraget til oplevelsen af de svækkede besøgstal (jf. Paldam 2012a; 2012b).

${ }^{4}$ Det er muligt, at denne type mismod er genkommende i kirkehistorien, at det ligefrem er et grundvilkår for kirkens mænd. Hans Raun Iversen har endvidere talt for det synspunkt, at udbredt frivillig kirke- og nadvergang er en undtagelsessituation i Danmark, og at det er et fænomen, som først opstår med vækkelsesbevægelserne. Overhovedet understreger han det anakronistiske ved at opfatte danskere i tiden før år 1800 som kristne i en moderne, frivillig og personlig forstand. Denne religiøsitet er i Danmark et produkt af det 19. århundrede, vækkelsesbevægelser og grundtvigianisme (Iversen 2000).

5 På sin vis kan dette fokus på kirkegangen anvendes som barometer for de komplekse historiske tendenser og processer, man ofte opsummerer under begreberne 'individualisering' og 'sekularisering'. Individualisering er således den komplekse proces, som indebærer en stadig tiltagende grad af specialisering og fragmentering af sociale grupper (f.eks. arbejdsdeling). Hertil kommer en stadig stærkere 


\section{Den INDERLige DELTAGELSE}

også en udmærket illustration i denne beklagelse, som en landsbypræst sender til sin storbyboende søn i netop den pågældende periode:

Paa sine Steder siger man det reent ud, at den gejstlige Stand er ganske undværlig (...) Du nævner nogle faa af Kiøbenhavns Præster, der have et eller mere eller mindre talrigt Auditorium; men at Kirkerne er dog i Almindelighed - i Forhold til Folkemængden - saa godt som ere tomme, at derimod Forsamlingsstederne af taabelige umoralske Gøglerier stedse ere fulde (citeret fra Koch 1954, 93).

Derfor forsøgte man sig i kirkelig regi med en række omstillingstiltag: Det underliggende ræsonnement blandt kirkens folk synes at være, at den svækkede opbakning måtte skyldes, at man ikke havde formidlet budskabet godt nok. Det resulterede blandt meget andet i nye katekismeudkast, nye bibelhistoriske lærebøger og nyoversættelser af Det Nye Testamente. Men gudstjenestens udformning blev genstand for en række længerevarende offentlig teologiske diskussioner. I forskningslitteraturen er det velkendt og afdækket, at præsternes prædikener og menighedernes salmesang var til diskussion. Som forsøg på at rette op på det første oprettede man Homeletisk Selskab i 1799, der 10 år senere blev omdøbt til Det Kongelige Pastoral Seminarium. Sangen forsøgte man at forbedre med salmebogen Evangelisk-Christelig Salmebog fra 1798. Disse forhold er kendt stof og gengivet i lærebøger og oversigtslitteratur omkring perioden. Men er ikke desto mindre afgørende at medtænke som baggrund for den forstålse af det religiøse fællesskab, Grundtvig formulerer fra 1820'erne og frem. Centralt i Grundtvigs syn på etableringen og vedligeholdelsen af fællesskabet er ikke mindst salmesangen.

\section{Fællesskab og fællessang}

Der er bred enighed om, at netop salmedigtningen er Grundtvigs nok vigtigste bidrag til kulturhistorien. Eksempler på formuleringer af denne

understregning af individets frihedsrettigheder. Processen regner reformationen, oplysningen, britisk liberalisme, fransk republikanisme og tysk idealisme som sine milepæle. Sekularisering er den lige så indviklede række af fænomener, der gradvist har adskilt religiøse spørgsmål fra verdslige. 
pointe er legio og findes såvel i som uden for forskningsudgivelser. I den mere populære ende af litteraturen kommer holdningen f.eks. til udtryk i Steen Johansens Grundtvig-tekstsamling Dejlig er den himmel blå (Johansen 1983, 7), mere bastant i Poul Borums Digteren Grundtvig (Borum 1983, 52), og endelig har Kirsten Thorup udtalt noget tilsvarende (Harder 1995, 74). I den praktisk-teologiske forskning, som beskæftiger sig indirekte med Grundtvigs betydning for folkekirken, genfindes holdningen, når Hans Raun Iversen med henvisning til Grundtvig siger, at "salmesangen er folkekirkens vigtigste praksis- og kommunikationsform" (2009, 1). I artiklen "Et rids af Grundtvig-forskningens stilling i efterkrigstidens Danmark" fremdrager Kim Arne Pedersen for sin del en repræsentant for Grundtvigforskningen og en for Grundtvig-formidlingen, der begge (efter Pedersens vurdering berettiget) betragter Grundtvig-salmerne som centrale i konstruktionen af 'danskhed' som sådan. Det drejer sig henholdsvis om William Michelsen og Finn Abrahamowitz. Han konstaterer:

Begge [Michelsen og Abrahamowitz] er de vidner om Grundtvigs enestående betydning i dansk kultur, vidner om, at kristendommens indflydelse på dansk bevidsthedsdannelse i vidt omfang går gennem Grundtvigs salmer, og at Grundtvigs tanker om kristendommens og danskhedens vekselvirkning har haft en virkningshistorie, hvis styrke vanskeligt kan overdrives (Pedersen 2002a, 13).

Det er på den baggrund ikke overraskende, at netop salmerne er genstand for et væld af undersøgelser, og at man ikke sjældent støder på formuleringer, der sætter salmerne forrest i forfatterskabet. ${ }^{6}$

Ikke desto mindre har de fleste undersøgelser ikke haft salmedigtningen som primærgenstand. Salmerne behandles oftest som illustrationer på andre forhold - f.eks. hvordan diverse teologiske pointer kommer til udtryk, eller hvordan anvendelsen af forskellige litterære motiver viser sig

\footnotetext{
${ }^{6}$ Sune Auken leverer et af de seneste eksempler herpå med sin formulering: “[E]n grundtvigsk teologi, som ikke har et meningsfyldt forhold til Grundtvigs salmer, er ikke en grundtvigsk teologi” $(2014,42)$. H.L. Martensens udtrykte det allerede i 1883 således: "Hos Grundtvig traadte Psalmen i Dogmatikkens Sted; i Psalmen fandt han og udtrykte han Troens Lærdomme" (Martensen 1882). Citatet og positionen er siden ofte blevet gentaget.
} 


\section{Den INDERLige DELTAGELSE}

heri. ${ }^{7}$ Sagt på en anden måde: Den forskning, der eksklusivt fokuserer på salmerne, er en mindre niche i forskningen generelt. Inden for denne gren af forskningen er det endvidere et fåtal, der har beskæftiget sig med andet end selve salmeteksterne. ${ }^{8}$ Men enkelte har, som jeg vil vise i det følgende, taget skridt i retningen af at afdække salmernes rituelle indlejring. Ikke desto mindre er det næppe urimeligt at betragte Grundtvigs forståelse af salmesangens funktioner som et forskningsmæssigt uopdyrket land. På baggrund af mit afhandlingsarbejde skal jeg her skitsere, hvorledes en afdækning af emnet kunne påbegyndes. Salmeteksterne konstituerer ikke et decideret empirisk blind spot, men de er bevidst trukket langt ud i undersøgelsens periferi. Jeg forholder mig til salmeudgivelsernes introducerende paratekster, til noteapparatet samt til subjektbrugen. Men herudover optræder der sporadiske parenteser om teksternes semantik og kun i det omfang, at de belyser Grundtvigs syn på tekstens funktion i det religiøse fællesskab.

\section{Religionsvidenskabelig forskning i Grundtvigs salmer}

Der har været forskningsmæssige ansatser til at gennemføre den opgave, jeg har stillet mig selv. I En glemt dimension i Grundtvigs salmer - bundetheden til dåbsritualet (1969) påpeger Christian Thodberg, at det er afgørende at tage højde for salmernes rituelle kontekst, for det er "den sammenhæng, der fastholder en salmes oprindelige mening" (Thodberg 1969, 8). For at kunne foretage en nuanceret analyse af en Grundtvigsalme, må man derfor beskæftige sig med det rum, den er tænkt ind i. Det rum udgøres af gudstjenestens prædiken, forkyndelse og forskellige ritualer, herunder særligt dåben (ibid.). Motoren i Thodbergs ritua-

\footnotetext{
${ }^{7}$ Eksempler på det første findes i Henning Høirups Grundtvigs syn på tro og erkendelse (1949, f.eks. 205) eller hos Harry Aronson, som har opdateret Martensen ved at opfatte Grundtvigs salmer som 'dogmer på vers', der først og fremmest udtrykker en velordnet teologisk økonomi (1960, 134, note 195). Noget tilsvarende ser man hos Thyssen $(1994,229)$ og i Helge Toldbergs Grundtvigs symbolverden (1950, 104; 201-208).

${ }^{8}$ Der samler sig dog en væsentlig gruppe af undtagelser omkring temaet 'Grundtvig-salmernes melodihistorie', hvoraf særligt Weyses, Berggrens og senere Laubs musikalske fortolkninger fremhæves (jf. Thyssen 1994).
} 
lorientering er imidlertid hermeneutisk: Den er nøglen, der låser op for den fortolkning af salmeteksten, som er hans primære fokus. Antagelsen er, at det rituelle var afgørende i salmens tilblivelsesfase, og at det derfor er et nødvendigt udgangspunkt for fortolkningsarbejdet. Dåben står centralt i Grundtvigs teologi, og det sætter sit præg på salmeteksterne, er det underliggende rationale. Selve idéen om den helt konkrete rituelle situation, hvor menigheden samlet synger i kirken, er da heller ikke central i Thodbergs fortolkning. Det er den derimod hos Søren Holm. Han understreger endnu tydeligere den rituelle kontekst og fokuserer på Grundtvig-salmen som brugstekst. I Mythe og Kult i Grundtvigs Salmedigtning 1955 finder Holm de samme tematikker i Grundtvigs salmer, som religionshistorikeren finder i primitive folks myter (f.eks. 'urtid og endetid', 'kosmiske magter i kamp' og 'natur og overnatur'). Derudover påpeger han, at Grundtvigs salmer er "Kirkesalmer. De er ikke beregnet på 'Kirke og Hjem' eller for Gudstjeneste og Husandagt; men de er for de allerflestes Vedkommende skabde med Kultfesten direkte for øje" (Holm 1955, 7). En videre tese hos Holm er, at Grundtvig forstår salmerne som kultiske brugstekster, som aktiverer deres mytiske indhold på en måde, der svarer til praksis i primitive religioner. Gennem denne aktivering regenererer salmerne i kraft af kultfællesskabet de skabende kræfter, som var på spil i de mytiske urhandlinger. Et af Holms belæg er, at Grundtvig i sin digtning hyppigt anvender den deiktiske markør 'i dag' (ibid., 162163). ${ }^{9}$ Mythe og Kult i Grundtvigs Salmedigtning fremstår som et forsøg på at kombinere aktuel religionsvidenskab - sandsynligvis under inspiration fra Mircea Eliade - med den Grundtvig, som i 2. Verdenskrig og op gennem resten 1940'erne havde gennemgået en folkelig revival (Pedersen 2003). Bogen blev senere enten ignoreret eller udskældt i forskningslitteraturen. Baggrunden herfor er samtidig en del af fortællingen om danske teologiske strømninger og Grundtvigforskningen i det 20. århundrede. Holm så Grundtvigs 'kultisk-mytiske kristendom' som en positiv tilbagevenden. Han mente således, at det var Grundtvigs "Genealitet, [at] han efter næsten halvtredie Tusind Aars Forløb atter kunde give Mythen for-

9 Den markør er i øvrigt også central hos Thodberg, som ser det som udtryk for Grundtvigs førnævnte græske inspiration eller 'vækkelse' (Thodberg 1993). Argumentationen er, at Grundtvig fra den græske kirkelige poesi overtager en præsentisk-eskatologisk teologi, som f.eks. kommer til udtryk ved den hyppige anvendelse af ordet hemera (i dag) (jf. Pedersen 2003, 160). 


\section{Den INDERLige DELTAGELSE}

nyet Liv i Religionens Verden" (Holm 1955, 227). Holm opfattede med andre ord salmeprojektet som en frugtbar arkaisering og remytologisering af kristendommen. Derfor er det ikke overraskende, at Kaj Thaning fandt det nødvendigt at kritisere Holms synspunkter (Thaning 1963, 596-604). Thaning var som så mange af samtidens teologer påvirket af Karl Barths dialektiske teologi og Rudolf Bultmanns eksistensteologiske afmytologiseringsbestræbelser. Han så Grundtvig som en sekulariserings-teolog, hvis væsentligste bedrift var at adskille det almenmenneskelige fra det rent kristne og at give det menneskelige førsteprioritet (jf. Nielsen 2002). Thaning kritiserede derfor Holms opfattelse af Grundtvig som 'primitiv' og fra den implicitte opfattelse, at kristendommen kan sammenlignes med andre religioner. Man hører ligefrem et barthsk ekko i Thanings kritik af Holms religionshistoriske tilgang til Grundtvig og salmerne:

[B]ruger man religionshistorien som hjælpemiddel til forståelse, begynder teksterne først at tale, når man når frem til det særlige, Grundtvig - så vel som Bibelen - har at sige. Ellers forsvinder "Meningen" i den religionshistoriske nat, hvor alle katte er grå. Ifølge Søren Holm har Grundtvig dog intet særligt sagt. Meningen hos ham er den samme som i de gamle folkereligioner (Thaning 1963, 599).

Thanings kritik er upræcis: Holms forståelse af Grundtvig og religionens form og indhold sigter ikke i sig selv på at udsige noget om Grundtvigs placering af religion i forhold til andre samfundsdimensioner. Grundtvig var moderne og sekulariseret, fordi han gjorde religion til en særlig sektor i samfundet. Det er Thanings synspunkt, men det er ikke et argument imod Holm. Misforståelsen beror på, at Thaning imellem de tre dimensioner samfund, kristendom og primitive religioner mener, at det kvalitative skel ligger mellem de primitive religioner og kristendommen. Holm lægger imidlertid snittet mellem kristendom og samfund.

Holms position synes i visse afgørende henseender at være foregrebet i religionshistoriker Edvard Lehmanns Grundtvig-biografi fra 1929. Også han fremhæver det indlysende kollektive aspekt ved Grundtvigs salmer: "Hvad han vilde, var [...] at skabe en kirkesang, og fra denne udelukker han med forsæt det individuelle så meget som muligt" (Lehmann 1929, 216). Derfor skriver Grundtvig sine salmer i første person pluralis, for "'vi' falder naturligere for fællessangen end et "jeg og du"” (ibid.). Endvidere ser 
Lehmann i selve Grundtvigs livsform inkarnationen af en arkaisk, verdensvendt livsførelse (Lehmann, 219-234). Religionshistorikeren Vilhelm Grønbech fremhæver desuden netop det kollektive og arkaiserende som Grundtvigs væsentligste kendetegn (Grønbech 1933). ${ }^{10}$ Hertil kommer, at disse pointer ofte siden er blevet gentaget i udgivelser, som står på randen af den egentlige forskning, og som må betragtes som brede og almene Grundtvig-indføringer. ${ }^{11}$ Det er desuden mit indtryk, at pointerne løber som velkendte figurer i miljøer, som kunne karakteriseres som grundtvigske: noget, man påpeger til diverse højskolearrangementer, til folkelige foredrag, under salmemaraton osv. Vi står her over for en linje, som i forskningen er blevet udskældt og marginaliseret som i Thaningeksemplet ovenfor, men som samtidig synes at have stået robust i den folkelige reception. I en vis forstand kan man også forstå min forskning som funderet i et ønske om at rehabilitere en religionsvidenskabelig tilgang, der ikke kunne finde rodfæste i en Grundtvigforskning, som i det 20. århundrede domineredes af teologer, der tænkte anderledes. Godt nok trænger både Lehmann, Grønbech og Holm til en række korrektioner og opdateringer; ${ }^{12}$ men jeg er overordnet enig i tilgangen, hvilket vil fremgå implicit af artiklens følgende afsnit. Ud over at særligt Holm og som nævnt Lehmann ikke kan betragtes som egentlige videnskabelige bidrag, hvad angår almindelige akademiske fremstillingsformers henvisningspraksis og eksplicitering af teoretiske inspirationer og metodisk fremgangsmåde, mangler deres behandling af salmerne en mere målrettet og vedholdende orientering imod det konkrete rituelle rum, som de ellers alle understreger, at de var tiltænkt. Undersøgelserne er, som for Thodbergs vedkommende, baseret på Grundtvigs salmetekster og underbelyser derfor i virkeligheden også det 'kultiske' eller 'rituelle'. I det følgende vil jeg skitsere nogle af Grundt-

10 Som også Kim Arne Pedersen har påpeget, finder man en tidligere variant af dette billede af Grundtvig som verdensvendt "livsdyrker" i Troels Lunds Bakkehus og Solbjerg, hvori han fantaserer over den mulighed, at salmen "Den signede dag" skulle have oldgamle, hedenske rødder (1920,170 ff.) (jf. Pedersen 2002a, 185, note 2).

11 De oplagte eksempler er Ebbe Kløvedal-Reichs Frederik. En folkebog om N.F.S. Grundtvigs tid og liv (1972) og Poul Borums Digteren Grundtvig (1983).

12 For Holms vedkommende ville min kritik være den samme som den rettet mod den teologiske forsknings oldkirke- og nutidsfokus, der giver et skævt billede af Grundtvigs ritualforståelse og salmesyn ved at glemme den emfatiske, kumulative historieinteresse, som ligger bag. 


\section{Den INDERLige DELTAGELSE}

vigs eksplicitte udsagn om salmesangens funktion, og på den baggrund gå videre i den overordnede undersøgelse af hans syn på sammenhængskræfterne i det religiøse fællesskab.

\section{Grundtvigs forståelse af fællessangens funktion}

Grundtvig ytrede flere gange i sit forfatterskab, at sangen er den centrale kristne udtryksform. Måden, hvorpå det kom til udtryk, forskubbede sig i løbet af hans liv og i takt med, at han fik flere erfaringer som præst og salmedigter. I Om Religion og Liturgie fra 1807 siger han, at:

Sangen [er] Middelpunkten af den liturgiske Poesie. Her maa alt hvad Mennesket kan frembringe Høit og Skiønt, forene sig. Poesien maa træde frem, klædt i det harmoniske Vers, hvilende paa det melodiske Riim, og hævet ved den potenserende Musik. Høit over Jorden maa vi opløftes, og et Glimt af det evige Liv maa svæve forbi vort mod Himlen stirrende Øie. Ak! Kun sielden skeer det, og hvad er Aarsagen? [...] saalænge Mængden af vore Kirkers Syngemestere endnu kunne lære meget af Bræger og Peer Degn, ville selv de skønneste Salmer tabe deres Kraft, og udbrede deres Dorskhed i stedet for dybe Følelse (Grundtvig 1807).

Dette æstetiske hovedkriterium for vurderingen af effekten af sangen, som viser sig i fremhævelsen af 'poesi' og 'harmoni', der forener endeligt med evigt, trådte med årene i baggrunden. At udviklingen skal tilskrives den pastoralerfaring, Grundtvig efterhånden opbyggede som kapellan i Udby og senere som præst i Præstø og ved forskellige kirker i København, og at den samtidig kan ses som en inspiration fra sang-praksissen i vækkelsesbevægelserne, er oplagt. Men de præcise biografiske omstændigheder tillader denne artikels rammer mig ikke at forfølge. Under alle omstændigheder beskæftiger Grundtvig sig en betragtelig del med salmesangens betydning for det kirkelige fællesskab, i takt med at hans salmeproduktion begynder at vokse i omfang i løbet af 1820'erne (men dog særligt fra 1837 og fremefter).

Særligt prægnante og eksplicitte overvejelser finder man i en anmeldelse af kollegaen P.A. Fengers udgivelse af et udvalg af Thomas Kingos salmer og 'aandelige Sange' fra 1828. Anmeldelsen er omkranset af en række 
overvejelser over, hvorledes den danske statskirke bør indrettes, således at præsten ud over at få mulighed for kirketugt og valg af lærebogsmateriale til konfirmationsundervisningen eksempelvis får frihed til selv at vælge den salmebog, han måtte finde passende (Grundtvig 1828, 9). I forlængelse af disse refleksioner forholder Grundtvig sig til sammensætningen af den ideelle salmebog. Inden for denne ramme formulerer han sit syn på salmens funktioner. I den bliver det tydeligt, at Grundtvig nu går pragmatisk og 'proto-sociologisk' til værks. Han tager således udgangspunkt i det uddannelsesmæssige niveau og i socioøkonomiske faktorer og er opmærksom på den situation, som flertallet af sangerne, de danske bønder og landalmuen, befandt sig i. Hvis en salme skal virke, må den med andre ord tage hensyn til dem, som skal synge den. Når størstedelen af modtagerne ikke er så gode til at læse, bør stavemåden derfor ikke være for besværlig. Men det var den i den stadig obligatoriske evangeliske salmebog. Melodierne burde efter samme logik heller ikke være for indviklede, når langt de færreste rundt om i sognene havde undergået nogen musikalsk specialtræning (Grundtvig 1828, 15).

Dette synspunkt harmonerer godt med nogle indirekte omstændigheder, der ses i Grundtvigs udarbejdelse af sine egne salmer: Han skrev dem ofte til i forvejen kendte melodier. Det kunne være nogle, som allerede var i kirkerepertoiret, men han brugte også folkelige melodier, som var fremmede i religiøs sammenhæng (Albeck 1967)..$^{13}$ Lundgreen-Nielsen har gengivet den 'fortælling', som er velkendt i Grundtvig-receptionen, at Grundtvig skulle have været særdeles umusikalsk, hvorfor man eksempelvis aldrig så ham til de koncerter, som ellers var en af samtidens mest almindelige kulturelle aktiviteter for det borgerskab, som han tilhørte (Lundgreen-Nielsen 1995, 112). Tilsyneladende havde han heller ikke

13 På den måde imødekom han det udbredte problem, at menigheden ikke kunne synge med på melodier, de ikke kendte. At det faktisk var et problem, vidner kantor ved Holmens Kirke Rudolph Bay om i sin Om Kirkesangen i Danmark og Midlerne til dens Forbedring fra 1840: "Almuen synger af Naturen slet; de høiere Classer ikke meget bedre, og tage for størstedelen eiheller Deel i Sangen i Kirken, deels fordi de ansee Prædiken for den eneste væsentlige Deel af Gudstjenesten, dels af Undseelighed for at lade deres Stemme høre, og deels fordi det nu er gaaet af Moden og kaldes gammeldags, ligesom Bordbønner m.m., og eneligen, fordi de ei kiende Psalmemelodierne, og i det hele ansee Choraler for den allerkjedsommeligeste og mest smagløde Musik” (citeret fra Thyssen 1994, 238-239). 


\section{Den INDERLige DELTAGELSE}

nogen nævneværdig kontakt til tidens største komponister E.F. Weyse, A.P. Berggreen, J.P.E. Hartmann, Henrik Rung og Niels W. Gade, som alle satte melodier til hans tekster (ibid.). ${ }^{14}$ Fafner har i forlængelse heraf foreslået, at Grundtvigs valg af melodi oftest var ureflekteret og tilfældigt, skønt det undertiden kan virke, som om han har tendens til at få en specifik melodi 'på hjernen' og derefter producerer en større mængde tekster, som netop tiltænktes den (1983). ${ }^{15}$ Men paratekstuelle momenter på omslag og i kolofoner etc. indikerer, at Grundtvig i hvert fald i bestemte tilfælde havde en gennemtænkt holdning til et afgrænset træk ved melodierne. Udgivelsen af den melodiløse sang "Dansk Seir-Sang. April 1848" ledsages således i en note af Grundtvigs anmodning om, at en given komponist vil udarbejde "en passende Melodi, saa rask og jævn som mueligt!” (jf. Damsgaard 2014, 108). Dette gælder for en martialsk fædrelandssang, som jo netop typisk er kendetegnet ved et hurtigt tempo, hvilket derfor i sig selv kunne være nok til at forklare Grundtvigs ønske om hastighed. Men skildringer fra Vartov-menigheden, hvor Grundtvig var præst fra 1839 til sin død, antyder, at Grundtvig satte pris på de hurtige melodier i almindelighed og i kirkelig sammenhæng. En række beretninger illustrerer eksempelvis, at salmesangen i Vartov virkede slående og særpræget på samtiden. Det indikerer, at Grundtvig omsatte sine tanker om den afgørende betydning af den 'inderlige Deltagelse' til praksis. Højskoleforstanderen Johan Borup fremhævede f.eks., at under en gudstjeneste i et af Grundtvigs "sidste Aar i Kirken" var der: "[H]elt anderledes Liv og Stemning end i de andre Kirker. Alle derinde sang med, alle hørte sammen som Venner, ingen Stivhed eller Højtidelighed" (Johansen og Høirup 1948, 256). Beskrivelsen er skrevet på 70 års afstand af en mand i det grundtvigske højskolemiljø, men bekræftes af den engelske adelsmand og digter Edmund Gosses velkendte beskrivelse af en af Grundt-

14 Berggren skulle endvidere være blevet inspireret af den type salmesang, der kom til at karakterisere Grundtvigs Vartov-menighed. Berggren ønskede at udbrede sangens 'livlighed' til hele den danske kirke. Men Grundtvigs pragmatiske omgang med melodivalget fandt han problematisk, for han mente, at der "bør drages en skarp Grænse imellem verdslig og kirkelig Sang” (1853, XIII).

15 Damsgaard (2014) tager afstand fra dette synspunkt og opfatter Grundtvigs melodilån som forsøg på at eksplicitere en intertekstuel pointe og skabe tilknytning til en anden tekst (108). Hans refleksioner gælder godt nok fædrelandssange, men kan rumme Grundtvigs melodibrug generelt. 
vigs sidste gudstjenester i Vartov. Menigheden sang ifølge Gosse salmerne "højt og hurtigt i et Staccato af Skjaldens egen Opfindelse; det lignede slet ikke den langsomme Sang i Statskirkerne" (ibid., 252). Beskrivelsen korresponderer i øvrigt med øgenavnet 'Vartov-galopader', som salmerne fik. Gosse beskriver desuden menigheden som "ekstatiske Tilhørere" med "fanatiske Ansigter" (ibid., 258-59). Endelig skriver grundlæggeren af den første norske højskole, O. Arvesen, i sine erindringer om en gudstjeneste i Vartov i 1856, at Grundtvig var en kortfattet, men 'glødende' prædikant, som 'greb' tilhørerne. Om 'Vartovs berømte salmesang' skrev han: “Det var den mest levende og fuldtonende kirkesang jeg nogensinde har hørt. Bjørnson, som i de dage meget ofte op holdt sig i Kjøbenhavn og da stadig besøkte Vartov Kirke, uttalte oftere at 'den salmesang er sterkere end nogen mission” (ibid., 227). Det er blot nogle få illustrationer af, at Vartov som menighed synes at have haft et omdømme, der baserede sig på en særlig grundtvigsk salme-praksis. Grundtvig synes med andre ord at have haft præferencer, hvad angår rytme og sværhedsgrad: Det afgørende var, at melodien forlenede salmen med en umiddelbar sangbarhed og et vist tempo. ${ }^{16}$ Ønsket om umiddelbar tilgængelighed satte sig desuden igennem i salmernes ortografiske udtryk, der er et helt andet end det øvrige forfatterskabs: De er nemme at overskue og indeholder f.eks. ikke Grundtvigs idiosynkratiske spatieringer, kursiveringer etc. (jf. Auken 2014, 42). I Fenger-anmeldelsen hedder det derfor, at en god salme er én, som er lettilgængelig, og som dur "til at sjunges eenstemmig i en Landsbykirke!" (ibid.). Den er ingen "Cantate til Applaus" (Grundtvig 1828, 15), ligesom menigheden ikke er et publikum, men aktive agenter i gudstjenesten. Det væsentlige for Grundtvig var netop den fælles deltagelse. Derfor så han det ikke længere - som han havde gjort i Om Religion og Liturgie - som et

16 Til ideen om denne Grundtvig-sang hører endvidere, at hastighed er relativ og at salmesangen i løbet af 1700-tallet for det første var blevet gjort isorytmisk, således at melodien bestod af lige lange nodeværdier. For det andet var melodierne blevet gjort stadig langsommere, så de næsten opløste sig i lange på hinanden følgende toner, hvorved den musisk-melodiske helhedsoplevelse udeblev. Peter Thyssen forbinder denne udvikling med den "romantiske forestilling om, at kirkemusikken først og sidst skulle befordre andagtsfølelsen hos den enkelte kirkegænger; musikken kunne på ypperlig vis bidrage til at give 'smag for det uendelige' (Schleiermacher). En sådan 'følelse for det uendelige' lod sig i kirkemusikken bedst formidle via brede og langsomt flydende tonestrømme!” (1994, 240). Denne andægtige lang-som(melig)hed gør Grundtvig op med. 


\section{Den INDERLige DELTAGELSE}

problem, at den religiøse og kulturelle elite ville savne poetiske og musiske kvaliteter i salmesangen:

Det maa vi lære, at denne tilsyneladende Opofrelse i Grunden ingen er, da det, der i Kirke-Sangen opbygger og rører os, langt mindre er Psalmen i sig selv betragtet, end Menighedens inderlige Deeltagelse i Den, hvad vi kun har glemt i Stæderne under Comedie-Skikken, at kige i Texten og høre paa Musiken (Grundtvig 1828, 31-32).

Det er først og fremmest deltagelsen i sig selv og ikke salmeteksten, der rører den syngende menighed, og som får individerne til: "naturligt at tilegne sig et fælles, simplet, levende og rørende Udtryk af Herrens Forjættelser, Aandens Trøst og Guds Børns Hjerte-Lag!” (ibid., 15-16). Han taler altså for det synspunkt, at salmen i kraft af den kollektive deltagelse i sangen lægger et fundament for individernes fællesskab.

Grundtvig omsatte disse refleksioner i sin salmevirksomhed. Både i de tekster, han forfattede, og også under sin tid som præst for Vartov-menigheden. Det fremgår af overvejelser, han gjorde sig i begyndelsen af 1860'erne:

[E]fter det Indtryk, Vartov-Forsamlingen med sin Menigheds-Sang, under Øgenavnet 'Grundtvigianisme', har gjort på Verden, ikke blot i Hovedstaden, men i hele Danmark, kan det dog næppe fejle, at der jo i den senere Menneske-Alder kjendelig har dannet sig en Kjærne til en kristelig dansk Frimenighed (citeret i Johansen og Høirup 1948, 112).

Fællessangen kunne altså fungere dels som ydre kendetegn på en bevægelse (Grundtvigianisme) og dels som kriterium for etableringen af et fællesskab på tværs af sognebånd (frimenighed).

\section{Sang-Varket som kirkehistorisk sampling}

Til trods for denne radikale betoning af forsamlingen og sangens betydning for det religiøse fællesskab og til trods for fremhævelsen af "den inderlige Deltagelse" i sangen frem for salmeteksten i sig selv (Grundtvig 1828, 31) forekommer interessen for salmeteksternes indhold dog indlysende: Han 
nyskrev og omskrev ikke mindre end 1571 salmer til udgivelse. Drivkraften synes at være ønsket om at formidle kirketraditionen med dens mange facetter og udtryk. Det førnævnte Sang-Verk til den danske kirke $(1837)^{17}$ kan i forlængelse heraf opfattes som et forsøg på at gøre hele kirkehistoriens sangtradition tilgængelig for moderne danskere. På titelbladet introducerer han de 401 salmer som "Sang-Værk til den Danske Kirke samlet og læmpet af Nik. Fred. Sev. Grundtvig Præst”. Han fremstiller således sig selv som den redaktør, der har indsamlet og tilpasset det foreliggende stof. Bag formuleringen 'samlet og læmpet' gemmer sig den omstændighed, at Grundtvig oversatte bestemte tekster inden for de forskellige kirkeperioder og -retninger (israelitisk, græsk, romersk-latinsk, angelsaksisk (og oldnordisk) og postreformatorisk tysk, engelsk og dansk) eller inspireredes af de tematikker og stilistiske træk, som kendetegner dem, og skrev nyt inden for disse rammer. 283 af de 401 salmer er udarbejdet på baggrund af et konkret forlæg. Dette fremgår af de fodnoter, hvormed Grundtvig har udstyret de salmer, der er blevet til som omformning af ældre materiale. ${ }^{18}$ Tilpasningsgraderne varierer på en akse, der spænder fra minimal til omfattende redaktion: "Af den Angel-Sachsiske Messiade i Exeter-Bogen" (SV I, 290), "Taget af Brorsons 'Mit Hjerte altid vanker" (383) og "Den Velbekjendte, næsten uforandret" (204). Mere omarbejdelse har fundet sted i "Kingos, efter Propheten Esaias i det 7de, lidt forandret" (368) og “'O hjertekiære Jesu Christ' forkortet og nænsom ændret” (513) og endnu mere i "En ny Fordanskning af Luthers 'Vom Himmel hoch da komm ich her' læmpet efter den gamle" (348), "Den Gamle opfrisket” (168) og "En Engelsk Sang 'Oh for the eye of faith divine' efterlignet" (635). I tilfælde som "Gammel-Græsk Søndags-Psalme, frit fordansket"19 (287), "Kingos,

17 I dag indgår den som første bind ud af fem, der samler Grundtvigs salmer og åndelige sange til brug i kirke, skole og hjem. Det sidste bind udkom i $1881 \mathrm{og}$ den samlede udgivelse hedder Sang-Vark. Jeg referer imidlertid udelukkende til 1837-udgivelsen, som er til kirkebrug.

18 En udførlig gennemgang af ideen med sangværk findes i: Solten, Therese Bering, Troens øjeblik. Et tematisk, hermeneutisk og genreorienteret studie i N.F.S. Grundtvigs salmer, Ph.d.-afhandling, Det Teologiske Fakultet, Københavns Universitet 2014.

19 Udtrykket 'fordanskning', som optræder mange gange i værket, er en vigtig Grundtvig-neologisme og i øvrigt den samme, som han anvender om sin oversættelsesteknik i arbejdet med Saxo og Beowulf. Den vidner om Grundtvigs ønske om at bidrage til traditionsformidlingen, som Anders Holm har kaldt 'det historiske stofskifte' $(2001,94)$. 


\section{Den INDERLige DeLtagelSE}

noget anderledes" (374) og "Med hensyn paa Esaias 66” (418) er forlæggene trukket langt tilbage.

Som vi så i Fenger-anmeldelsen, er det væsentligt, at teksterne er sangbare og kan synges i samtidens landsbykirker. Derfor skal de tilpasses tidens genreforventninger. Balancegangen for Grundtvig synes at være ønsket om at fastholde det særprægede og egenartede samtidig med at skabe en tilpas mængde anknytningspunkter, der gør teksterne umiddelbart vedkommende for brugerne. Det slår igennem både på det metrisk-formmæssige niveau og på det indholdsmæssige i billedsproget. De gammeltestamentlige Davidsalmer kommer således på strofer, så de kan synges i fællesskab. Naturbillederne i de græske og latinske hymner skiftes ud med billeder hentet fra dansk flora og fauna, så de særprægede og gamle kirkeslige strømninger knyttes til et billedunivers, som vækker umiddelbar genkendelighed hos de syngende. De postreformatoriske salmers regelløse metrik gør han regelmæssig (jf. Auken 2013, 43). Endelig omformer Grundtvig en lang række salmer fra den danske tradition hos Nordahl Brun, Kingo og Brorson, så de bliver tilpasset fællessangens kollektive ramme - her er transformationen ofte den, at salmer enten med subjekt i singularis eller med skjult agens bliver til salmer med klart defineret subjekt i pluralis. Sang-Varket er således en opdatering og formidling af den kirkehistoriske salmeakkumulering, som forsøger at eksponere de distinkte kendemærker, der knytter sig til de forskellige kilder. Sagt med andre ord: På samme måde som en DJ kan sample og sammensætte elementer fra gamle, halvglemte sange og i kraft af den nye kontekst give dem nyt liv og et nyt udtryk, redigerer, opdaterer og formidler Grundtvig det kirkehistoriske bagkatalog. Sang-Varket blev til i tiden omkring 1836-jubilæet, der markerede reformationens indførelse i Danmark - og var både et bidrag til og en reaktion på fejringen. At det netop er en del af motivationen bag Sang-Verk giver Grundtvig udtryk for i et brev til Ingemann fra 1836 (jf. Lundgreen-Nielsen 1995, 108, note 7). Det første hæfte af værket blev da også udgivet allerede i 1836. At salmekompilationen så tydeligt har til formål at samle de mange kirkestrømninger - også dem, som man under reformationen gjorde op med - kan da også i sig selv ses som en implicit implementering af en kritik af reformationsbruddet.

I Sang-Verket giver han sit bud på restaureringen af den kirkehistoriske diskontinuitet $\mathrm{i}$ et bærbart og sangbart format rettet mod den brede befolkning. At man heri samtidig kan læse et generelt ønske om restaure- 
ring af en kirke, hvis besøgstal siden 1799 havde lidt under en upopulær salmebog, kan understøttes af selve titlen. 'Sang-Værk' var kaldenavnet på det klokkespil på Frue Kirke, som blev ødelagt under bombardementet i København 1807, og som Grundtvig symbolsk ønskede at genetablere. Anders Holm opfatter i Historie og Efterklang. En studie i N.F.S. Grundtvigs tidsskrift Danne-Virke de såkaldt 'efterklangsdigte', som Grundtvig under en række forskellige intertekstuelle greb skriver til tidsskriftet, som udtryk for at "tanken om omstøbningen af fædres malm til en klokke, som kan spille en ny lyd, der har betydning for nutid og fremtid (...) hele tiden [er] nærværende. Der er således i høj grad tale om en hermeneutisk tankeform” $(2001,71)$. Jeg mener, at denne hermeneutik også slår igennem i Sang-Vark.

\section{Ligevægtspunkt mellem tyngde og lethed}

Grundtvig var vidne til en kirke i krise, og han opfattede det kirkelige fællesskab som udfordret på flere sammenføjede måder: Den udvikling, der stadig var et elitært fænomen, og som kombinerede stigende individualisering og den rationelle refleksions tiltagende dominans, havde i kirke-regi og blandt andet gennem udbredelsen af den historisk-kritiske metode betydet en underminering af tiltroen til bibelen og dens beretningers sandhed og herigennem kirkens fundament. ${ }^{20} \mathrm{Hvad}$ der før fremstod urokkeligt og indiskutabelt, blev genstand for diskussion. Man forsøgte

${ }^{20}$ Grundtvig er påfaldende moderne på dette punkt. Individualiseringen og erkendelsen af ikke kun før-oplysningen, men også oplysningens og modernitetens traditioners erosion har således kendetegnet den tankestrømning, man har kaldt 'det postmoderne'. Et begreb, som havde sin storhedstid i 1980'erne, og som Milan Kundera fangede essensen af i Tilvarelsens ulidelige lethed (som i øvrigt synes at spille på René de Chateaubriands idé fra begyndelsen af 1800-tallet om en mal de l'inifini - uendelighedens sygdom: en eksistentiel tilstand eller lidelse, som følger af den moderne virkeligheds grundlæggende meningsløshed). Netop i 1980'erne adresserede Helmuth Friis oplevelsen af erosion, vilkårlighed og absurditet i sin teologiske essaysamling Den løse mening (1987). Den afsluttende analyse er, at "sammenbruddet af den tidligere orden er mindre en katastrofe end en befrielse til og åbning af livets egen orden: helhedsdannelsen, plantens, talens, dialogens, dansens, forførelsens, de spontane livsytringers, nødvendige eksistensmåders orden [...] Det drejer sig ikke om sandhed og norm, men om livskraft contra død, sådan som vi ser det hos Nietzsche, Grundtvig og Løgstrup” (Friis 1987,157). 


\section{DeN INDERLIGE DELTAGELSE}

med argumenter at holde en snigende fornemmelse af vilkårlighed fra døren. Men ikke alene var dét ikke lykkedes. Man havde samtidig drevet lægmandskristne bort fra kirken med den komplicerede og kedelige teologi, som var produktet af bestræbelserne, og som fyldte prædikener og salmer. ${ }^{21}$ Han formulerede sit løsningsforslag på to måder - til to målgrupper. Det teologisk-argumentative forslag i Kirkens Gienmale, som er målrettet en uddannet elite, er, at man definerer kirken i kraft af tradition og praksis og ikke i kraft af teologisk diskussion. Det implicitte forslag i salmerne, som henvender sig til alle danske kirkegængere, er, at man jævnligt synger sammen og således både genopfrisker fællesskabsfølelsen (i kraft af fællessangen) og forestillingsindholdet (i kraft af teksten). Salmerne kan således opfattes som Grundtvigs sangbare bolværk mod modernitetens trusler. Den underliggende logik er, at fællessangen og teksten forholder sig korrelativt til de to grundpiller, som skal hjælpe med at bære tilværelsens ulidelige lethed: de fysiske forsamlingers materielle forankring af fællesskabet (Hutchins 2005) og historiens og traditionens indholdsmættede fiksering af trosindholdet. Grundtvig anvender de samme piller i fundamentet for det verdslige fællesskab, men det falder uden for artiklens rammer at redegøre for det her. I stedet vil jeg henvise til min artikel "Grundtvig og det folkelige foredrag", der indgår i Ved lejlighed. Grundtvig og genrerne (2014).

\section{Litteratur}

Aronson, Harry (1960), Mänskligt og kristet. Et studie i Grundtvigs teologi, Stockholm.

Albeck, Gustav (1967), "N.F.S. Grundtvigs forhold til musik og billedkunst” i Växelverkan kan mellan skönlitteraturen och andra konstarter, Stockholm.

Auken, Sune (2008), "Nordisk mytologi og salmedigtning - N.F.S. Grundtvig" i Dansk litteraturs historie bind 2, København.

Auken, Sune og Christel Sunesen, red. (2014), Ved Lejlighed. Grundtvig og genrerne, København.

${ }^{21}$ Dette er min naturligvis min syntese af Grundtvigs samtidsdiagnose(r), som faldt lejlighedsvist og kontekstbestemt. Men alligevel er der på dette felt en vis konsistens, som gør det rimeligt at behandle det som et samlet hele. 


\section{Katrine FrøkjÆr Baunvig}

Baunvig, Katrine Frøkjær (2015), "Come Together. Thoughts and Theories on Social Cohesion in the Work of Nikolai Grundtvig and Émile Durkheim” i John A. Hall og Ove Korsgaard (red.) Building the Nation. N.F.S. Grundtvig and Danish National Identitet, 232-253, Montreal (under udgivelse).

- (2014a), "Durkheim og 'Religionens fremtid"” i Religionsvidenskabeligt Tidsskrift 61, 108-121.

- (2014b), "Det folkelige foredrag” i Sune Auken og Christel Sunesen (red.), Ved Lejlighed. Grundtvig og genrerne, København, 66-94.

Bennett, Tony (1995), The Birth of the Museum. History, Theory, Politics, London.

Borum, Poul (1983), Digteren Grundtvig, København.

Damsgaard, Johan (2014), "Fædrelandssangen” i Sune Auken og Christel Sunesen (red.), Ved Lejlighed. Grundtvig og genrerne, København, 95-123.

Fay, Elizabeth (2002), Romantic Medievalism. History and the Romantic Literary Ideal, New York.

Friis, Helmut (1987), Den løse mening, Aarhus.

Grundtvig, N.F.S. (1807), “Om Religion og Liturgie” set på http://www. grundtvigsværker.dk

- (1825), Kirkens Gienmale: imod Professor Theologia Dr. H.N. Clausen, København.

- (1828), "Psalmer og aandelige Sange af Thomas Kingo, samlede og udgivne af P.A. Fenger, Præst 1827” i Theologisk Maaneds-Skrift XIII, 1-36, København.

Grønbech, Vilhelm (1933), "Kierkegaard og Grundtvig” i Kampen om Mennesket, København.

Harder, Thomas (1995), Om folkelighed, København.

Holm, Anders (2001), Historie og efterklang. En studie i N.F.S. Grundtvigs tidsskrift Danne-Virke, Odense.

Holm, Søren (1955), Mythe og Kult i Grundtvigs Salmedigtning, København.

Høirup, Henning (1949), Grundtvigs Syn paa Tro og Erkendelse. Modsigelsens Grundsatning som teologisk Aksiom hos Grundtvig, København.

Iversen, Hans Raun (2000), "Hvad ved vi om kirkegang” i Roskilde Stiftsbog 2000.

- (2009), “Kristendommen sidder i kroppen”, set 7.11.2014: http://www.teol. $\mathrm{ku} . \mathrm{dk} / \mathrm{ast} /$ arrangementer/20091116.

Jakobsen, Tove B. (2007), “Arbejdet i Oldsagskommisionens første år” i Årbøger for nordisk Oldkyndighed og Historie 2007, set 7.11.2014: http://oldskriftselskabet.dk/aarboeger.htm.

Johansen, Sten (1983), Dejlig er den himmel blå, København. 


\section{Den INDERLIGE DELTAGELSE}

Kløvedal-Reich, Ebbe (1972), Frederik. En folkebog om N.F.S. Grundtvigs tid og liv, København.

Koch, Hal (1954), Den Danske Kirkes Historie IV, København.

Lehmann, Edvard (1929), Grundtvig, København.

Lundgreen-Nielsen, Flemming (2010), “'I som raver i blinde’. Arkæologer og antikvarer set af danske romantiske digtere i 1802-20” i Årbøger for nordisk Oldkyndighed og Historie 2010, http://oldskriftselskabet.dk/aarboeger.htm.

- (1995), "Grundtvig og guldalderens København” i Grundtvig-Studier 1995, 107-139, København.

Martensen, H.L. (1883), Af mit Levned II, København.

Nielsen, Mikkel Crone (2002), “'At tale med de døde...' Om sækularisering og hermeneutik i Kaj Thanings forfatterskab” i Grundtvig-Studier 2002.

Paldam, Martin (2012a), The religious transition. A long run perspective, København.

- (2012b), Church density and the church membership ratio. The cross-municipal pattern in Denmark, København.

Pedersen, Kim Arne (2002a), "Et rids af Grundtvig-forskningens stilling i efterkrigstidens Danmark" i Grundtvig-Studier 2002.

- (2002b) "William Michelsen in memoriam" i Grundtvig-Studier 2002, 11-23.

- (2003), "Den Teologiske Grundtvigforskning siden Anden Verdenskrig" i Hanne Sanders og Ole Vind (red.), Grundtvig - Nycklen till det danska?, Stockholm, 150-179.

Thaning, Kaj (1963), Menneske først - Grundtvigs opgør med sig selv, København. Thodberg, Christian (1969), En glemt dimension i Grundtvigs salmedigtning - bundetheden til dåbritualet, København.

- (1993), "Den græske vækkelse” i Dansk Kirkesangs Arsskrift, 1993.

Thyssen, Peter (1994), "Grundtvig, Laub og kirkesangen” i Grundtvig-Studier 1994, 229-256.

Toldberg, Helge (1950), Grundtvigs symbolverden, København. 